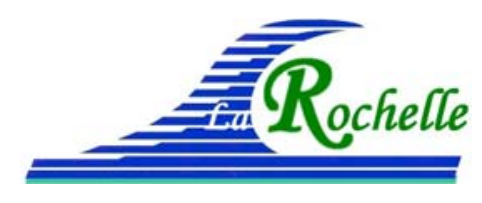

XV $V^{\text {èmes }}$ Journées Nationales Génie Côtier - Génie Civil

La Rochelle, 29 au 31 mai 2018

DOI:10.5150/jngcgc.2018.032 (C) Editions Paralia CFL

disponible en ligne - http://www.paralia.fr - available online

\title{
Modelling cohesive sediment vertical dynamics relative to the Estuarine Turbidity Maxima of the Loire River estuary
}

\section{Martin SANCHEZ ${ }^{1}$}

\author{
1. Université de Nantes, UMR-6112 CNRS - Planétologie et Géodynamique, \\ 2 rue de la Houssinière, 44322 Nantes cedex 3, France. \\ martin.sanchez@univ-nantes.fr
}

\begin{abstract}
:
The vertical dynamics of cohesive sediments is studied in the maximum turbidity zone of the estuary of the river Loire (France). The modelling of major sedimentary processes is studied taking into account mechanical and rheological properties of sediments. The values of the site-specific constants intervening in the models have been evaluated through field and laboratory measurements.

A 1D vertical schematic model has been implemented to simulate the cohesive sediment dynamics in the estuarine turbidity maxima. Results issued from this schematic model can be used to estimate the uncertainty of settling velocity evaluations from in situ measurements of vertical concentration profiles.
\end{abstract}

Keywords: Cohesive sediments, Settling rate, Settlement, Erosion, Sedimentation, Loire estuary.

\section{Introduction}

The general configuration of the Loire estuary has practically not changed for the last 6000 years, since the end of the last glacial period (PINOT, 1998). At the peak of this glaciation, 16000 years ago, the global sea level was about $120 \mathrm{~m}$ lower than the present level. In the majority of cases, the low river valleys which were drowned by the sea at the time of this sea level rise have been filled by sediments. These sediments cover the topographic irregularities of the old banks.

The sediments which filled the estuaries are mainly cohesive materials mixed with a variable fraction of silt and sand. These materials consist of clays which have been eroded by rain waters, siliceous and calcareous organism remains, various salts and oxides, more or less decayed organic matter (up to approximately $10 \%$, but variable from an estuary to another), and interstitial water.

This is why a very great quantity of consolidated fine sediments is found in the estuaries in the form of rigid mud representing the equivalent of several centuries of the fluvial solid inputs. The accumulation of fine sediments in the estuaries is explained by the hydrodynamics resulting from the mix of two waters with different densities, in a zone affected by tides, where the suspended matter deposition can occur easily at slack water. 


\section{Thème 2 - Dynamique sédimentaire}

In addition to the transport in suspension of sediments, the main sedimentary processes observed are:

a) deposition, quiescent conditions which occur at slack water allow in all the cases a transfer of the suspended sediments towards the consolidated rigid mud bed, and in some particular cases, part of the deposited sediment gathers near the bed to form a layer of fluid mud;

b) fluid mud settlement, an increase of the concentration is caused by the sediment's own weight;

c) erosion, when flow velocities increase sufficiently, they cause resuspension of fluid mud, creating an estuarine turbidity maxima (ETM); in the Loire, the ETM is characterized by a suspended sediment concentration 10 to 200 times higher than that observed in the river waters.

In this note, the main sedimentary processes intervening in the vertical dynamics of cohesive sediments are studied for the ETM of the Loire estuary (figure 1). Table I presents a number of parameters characteristics of this estuary.

The "mobile sediment" in an ETM is composed of the whole of the solid mass in suspension and in the layers of fluid mud. In the Loire estuary it consists of about $1 \times 10^{9} \mathrm{~kg}$ (CSEEL, 1984; DELFT HYDRAULICS, 1994). This quantity is equivalent to the incoming mass in suspension from the river over an 8-month period, in normal conditions. The "mobile sediment" stock in an estuary results from a balance between fine-grained sediment fluvial inputs, expulsions of materials towards the sea, dredging works, and exchanges with the rigid mud stock.

Table 1. Parameters characteristics of the Loire estuary.

\begin{tabular}{|c|c|}
\hline Parameter & Value \\
\hline Mean flow of the river & $825 \mathrm{~m}^{3} \mathrm{~s}^{-1}$ \\
\hline Maximum annual flow of the river & $5200 \mathrm{~m}^{3} \mathrm{~s}^{-1}$ \\
\hline Minimum annual flow of the river & $77 \mathrm{~m}^{3} \mathrm{~s}^{-1}$ \\
\hline Depth at the mouth (from the mean water level) & $16.50 \mathrm{~m}$ \\
\hline Maximum length near the mouth & $3500 m$ \\
\hline Period of the tide & $12 \mathrm{~h} 25^{\prime}$ \\
\hline Maximum tidal height at the mouth & $6.40 \mathrm{~m}$ \\
\hline Tidal prism in spring tides & $\sim 2.5 \times 10^{8} \mathrm{~m}^{3}$ \\
\hline Maximum penetration of the dynamic tide & $\sim 100 \mathrm{~km}$ \\
\hline Maximum length of the salinity intrusion & $\sim 70 \mathrm{~km}$ \\
\hline Average concentration in the river water & $\sim 0.06 \mathrm{~kg} \mathrm{~m}^{-3}$ \\
\hline Introduction of suspended sediments from river & $\sim 1.5 \times 10^{9} \mathrm{~kg}_{\text {year }}-1$ \\
\hline Expulsion of suspended sediments to the sea & $\sim 0.5 \times 10^{9} \mathrm{~kg}_{\text {year }}{ }^{-1}$ \\
\hline Silting rate in the estuary & $\sim 1.0 \times 10^{9} \mathrm{~kg}_{\text {year }}{ }^{-1}$ \\
\hline Average annual dredging from maintenance & $\sim 3.3 \times 10^{6} \mathrm{~m}^{3}$ \\
\hline Average length of the fluid mud layer & $\sim 12.5 \mathrm{~km}$ \\
\hline Average length of the maximum turbidity zone & $\sim 20 \mathrm{~km}$ \\
\hline Average stock of "mobile cohesive sediment" & $\sim 1.0 \times 10^{9} \mathrm{~kg}$ \\
\hline Introduction of sand from the river & $\sim 1.5 \times 10^{8} \mathrm{~kg}_{\text {year }}{ }^{-1}$ \\
\hline
\end{tabular}




\section{XVèmes Journées Nationales Génie Côtier - Génie Civil \\ La Rochelle, 29 au 31 mai 2018}

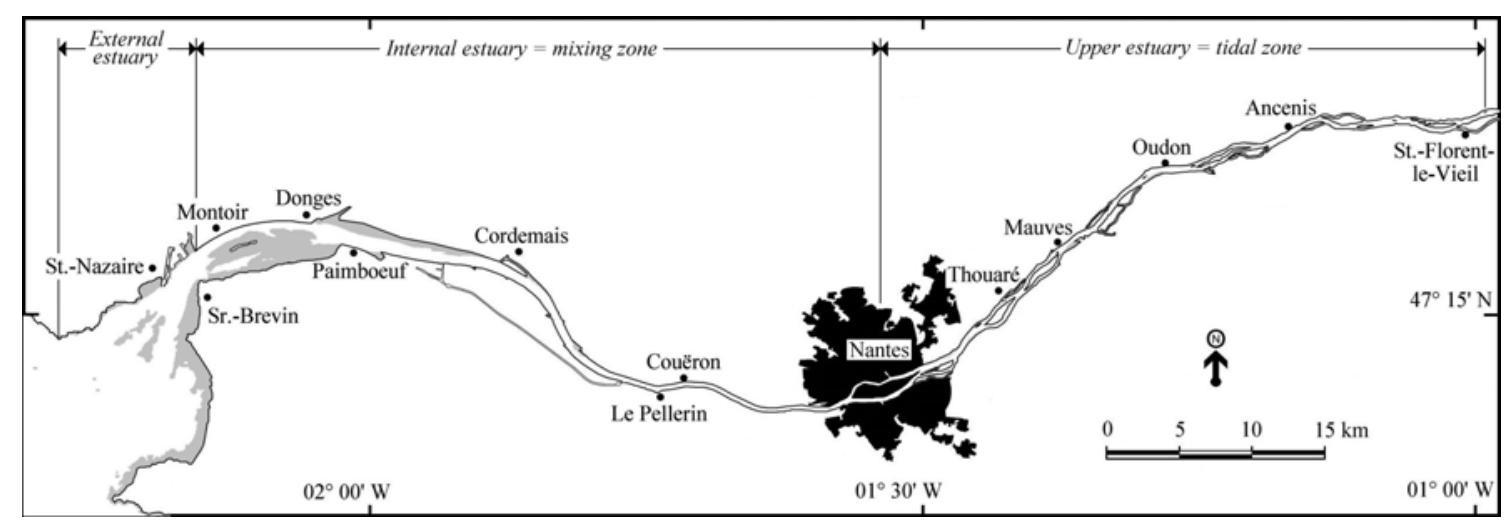

Figure 1. The Loire estuary (France).

The "mobile sediment" dynamics in the Loire estuary is associated with the fortnightly cycle of tide as follows (GALLENNE, 1974; CSEEL, 1984): in neap tides (for a tidal coefficient less than 0.70) almost all the sediments collect at the bottom of the estuary channel as a fluid mud and only a small part of this fluid mud is temporarily suspended during a tidal cycle, whilst at spring tides a great part of the fluid mud is taken again into suspension, and only the fraction which was sufficiently concentrated in the course of the fluid mud settlement remains continuously on the estuary bed.

Figure 2 which shows locations in the Loire estuary of the fluid mud layers, estuarine turbidity maxima and landward limit of salinity intrusion at 0.5 PSU (Practical Salinity Units), proves that these three locations are linked.

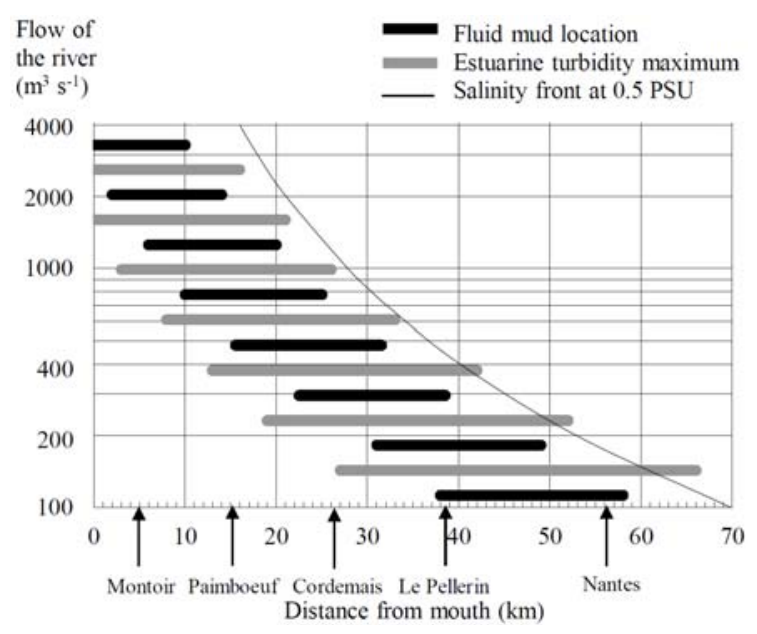

Figure 2. Approximate fluid mud and estuarine turbidity maxima location and extent, and position of the salinity landward limit at 0.5 PSU (plotted from data published by MIGNIOT and LE HIR (1994)).

In the Loire estuary, the average dimensions of the layer of fluid mud are $12500 \mathrm{~m}$ long, $300 \mathrm{~m}$ wide and $2 \mathrm{~m}$ high. Sediment concentration within the fluid mud varies between 40 and $325 \mathrm{~kg} \mathrm{~m}^{-3}$ with a vertical gradient which is a function of settlement time (the 


\section{Thème 2 - Dynamique sédimentaire}

value of $325 \mathrm{~kg} \mathrm{~m}^{-3}$ is quite arbitrary, it corresponds roughly to the limit detected by ultrasound sounders emitting in two frequency bands, and corresponds also to the concentration above which the mud is sufficiently rigid not to be eroded by the currents observed in the estuary).

The sediment found in the estuary bottom is in close relationship to the hydraulic conditions observed in each sector. Thus in the upper estuary (figure 1) the sand is the predominant bed sediment. Within the internal estuary the cohesive sediment prevails in the bed.

The in situ localization of the ETM according to the hydrological conditions and the evaluation of the stock of "mobile sediment", are two topics of great importance in the study of sedimentary dynamics. The cubature of the fluid mud formations detected with the assistance of an ultrasound sounder in neap tides is the most reliable method to evaluate the stock of "mobile sediment". The monitoring of the fluid mud in neap tides potentially represents one of the best means to know with one week of anticipation, the localization and the extent of the ETM at the time of the following spring tides.

\section{States of the sediment-water mixtures in terms of concentration}

According to the solid concentration, the sedimentary processes affecting downward vertical dynamics of the cohesive sediments are:

a) settling and deposition of the suspended matter;

b) settlement of the highly concentrated suspensions;

c) consolidation of the deposits.

The states of the sediment-water mixtures associated with these processes are respectively:

a) diluted suspension;

b) highly concentrated suspension or fluid mud;

c) rigid mud deposit with significant effective stress from the point of view of the soil mechanics.

Whatever the sedimentary process considered, the main parameter characterizing the downward vertical dynamics of the sediments is the solid phase velocity under the force of its own weight. Velocities of the solid phase, depending on the states of the sediment-water mixture quoted above are respectively:

a) settling velocity of the suspended matter which depends on suspended aggregate characteristics;

b) settlement velocity which depends on fluid mud permeability;

c) consolidation velocity which depends on the permeability and effective stress of the rigid mud.

In the ETM of the river Loire the two major sedimentary processes affecting downward vertical dynamics are suspended matter settling and fluid mud settlement, because these two processes affect the "mobile sediment" stock. The phenomenon of consolidation 


\section{XVèmes Journées Nationales Génie Côtier - Génie Civil \\ La Rochelle, 29 au 31 mai 2018}

acting on the rigid mud deposits with effective stresses is a secondary sedimentary process because it relates to a free-erosion sediment stock.

\section{Modelling of sedimentary processes}

\subsection{Settling of the suspended sediment}

The settling process descriptor considers that the local settling velocity of the suspended sediment mass is gamma distributed (SANCHEZ, 2006). The parameter $r$ of this distribution characterizes the range of settling velocity values for all the sediments simultaneously in suspension. Typical values of the parameter $r$ vary between 0.65 and 1.50. The mean settling velocity of the bottom sediments and the parameter $r$ of the gamma distribution, are both linked to the reference value of the bottom concentration. The vertical variation of the local mean settling velocity $W$ is depending on the hydrodynamic actions and the parameter $r$.

\subsection{Fluid mud settlement}

The fluid mud settlement model is based on a classical theory of sedimentation for materials without effective stresses (KYNCH, 1952; BEEN, 1980). This model takes into account the permeability coefficient of the fluid mud (SANCHEZ \& LEVACHER, 2007). The concentration on the surface of a fluid mud layer resulting from a flux of suspended sediment to the bed can be evaluated with this model (SANCHEZ, 2012).

\subsection{Mud erosion}

The cohesive resistance of Loire sediments is characterized from yield stress $\tau_{y}$ measurements carried out by HOSSEINI (1999) using a Brookfield LVT rheometer in accordance with the experimental step described by MIGNIOT (1989).

The beginning of the resuspension is defined for a residual erosion velocity $E_{v o}=3 \times 10^{-7} \mathrm{~m} \mathrm{~s}^{-1}$ (equivalent to an eroded layer $1 \times 10^{-3} \mathrm{~m}$ thick, in an hour). The critical bed shear stress for erosion $\tau_{c e}$ is linked to yield stress (SANCHEZ et al., 2000). For $\tau_{0}<\tau_{c e}$ the erosion velocity of the mud layers is calculated by a law similar to that used by DELO and OCKENDEN (1992) and CERCO et al. (2000). For $\tau_{0} \geq \tau_{c e}$ the retained law has been used by MEHTA and PARTHENIADES (1982).

\subsection{Modelling of the deposition rate}

The deposition rate is modelled from the settling process descriptor, the fluid mud settlement model, and the mud erosion law, without using a critical threshold shear stress for deposition as in Krone's law (KRONE, 1962).

In fact, in this study the cohesive sediment deposition rate in the Loire estuary is simulated through a simultaneous modelling of suspended sediment settling, fluid mud settlement and fluid mud erosion caused by a turbulent flow. The adherence forces to 


\section{Thème 2 - Dynamique sédimentaire}

the mud of the suspended aggregates reaching the bottom are modelled as cohesion forces characterized by a yield stress equivalent to that measured using a Brookfield LVT rheometer (SANCHEZ, 2012).

Even if most of the laboratory results indicate that mud erosion and suspended sediment deposition are mutually exclusive processes (MEHTA, 1986; LAU \& KRISHNAPPAN, 1994), for practical modelling purposes, as in this note, several researchers have considered simultaneous erosion and deposition, without a critical shear stress for deposition (SANFORD \& HALKA, 1993; CERCO et al., 2000).

\section{Schematic modelling of the vertical sedimentary dynamics in the estuarine turbidity maxima of the river Loire}

A 1D numerical model of the vertical sedimentary dynamics in the estuarine turbidity maxima of the river Loire has been carried out. The simplifying hypotheses are: negligible horizontal advection and diffusion, homogeneous transversal distribution of the sediments, constant depth $d=16 \mathrm{~m}$, estuary length 6 times greater than the length of the channel which is covered by the layer of fluid mud. Then, the vertical movement of fine sediments can be expressed by assuming Fickian mass diffusion as:

$\frac{\partial C}{\partial t}=\frac{\partial}{\partial z}\left(W C+K_{z} \frac{\partial C}{\partial z}\right)$

where $z$ is the vertical coordinate (positive upwards), $K_{z}$ is the vertical eddy diffusivity coefficient which in this study is modelled by:

$K_{z}=\beta U_{*} d$

where $\beta=0.067$ is an empirical constant and $U *=\left(\tau_{0} / \rho\right)^{0.5}$ is the shear velocity defined from bed shear stress $\tau_{o}$ and water density $\rho$. The parameter $\tau_{o}$ is calculated in terms of the surface flow velocity $U$ by:

$\tau_{o}=c_{f} \rho \frac{U^{2}}{2} \quad$, with the local friction coefficient given by: $\quad c_{f}=0,034\left(\frac{\varepsilon}{d}\right)^{1 / 3}$

where $\varepsilon$ is the hydraulic roughness. The surface flow velocity $U$ is modelled with the following sinusoidal law:

$U=U_{\text {max }} \sin \left(2 \pi \frac{t}{T}\right)$

where $T$ is the tide period and $U_{\max }$ is the amplitude of $U$ which is calculated by the following equation based on field observations within the maximum turbidity zone:

$U_{\max }=0.41+0.71 \mathrm{c} \quad$, in $\mathrm{m} \mathrm{s}^{-1}$

where $c$ is the tidal coefficient (ranging between 0.20 for the minimum neap tide and 1.20 for the maximum equinox spring tide). The tidal coefficient is modulated through the harmonic law below:

$$
c=\frac{c_{\max }+c_{\min }}{2}+\frac{c_{\text {max }}-c_{\min }}{2} \cos \left(2 \pi \frac{t}{T_{m}}\right)
$$




\section{XVèmes Journées Nationales Génie Côtier - Génie Civil \\ La Rochelle, 29 au 31 mai 2018}

where $C_{\max }$ and $C_{\min }$ are respectively the maximum and minimum tidal coefficients taken for the modellings $\left(c_{\max }=1.10\right.$ and $\left.c_{\min }=0.30\right)$ and $T_{m}$ is the period modulating the tidal heights $\left(T_{m} \approx 28 T\right)$.

Deposition rate, fluid mud settlement and erosion rate are modelled by the descriptors briefly presented in section 3 of this note.

The solution of the vertical mass movement equation (equation 1) is realised with a finite differences method dividing the water column in $50 \mathrm{~d} / 50$ thick sublayers, and by using a time step $\Delta t=0.5 \mathrm{~s}$ for the calculation. The fluid mud settlement is simulated by using $n=50$ sublayers with $C_{1}=325 \mathrm{~kg} \mathrm{~m}^{-3}$ and $C_{n}=40 \mathrm{~kg} \mathrm{~m}^{-3}$. The concentration difference between two adjacent mud sublayer interfaces is then equal to $5.816 \mathrm{~kg} \mathrm{~m}^{-3}$.

The modelling starts at slack water in spring tides with a tidal coefficient $c_{\max }$. The initial value for the suspended sediment concentration is $C=0.040 \mathrm{~kg} \mathrm{~m}^{-3}$, depth invariant. The fluid mud deposits are initialized with $200 \mathrm{~kg} \mathrm{~m}^{-2}$ of dry sediment having a concentration of $180 \mathrm{~kg} \mathrm{~m}^{-3}$ (deposit of $1.11 \mathrm{~m}$ of fluid mud with a yield stress $\tau_{y}$ equal to $2.92 \mathrm{~N} \mathrm{~m}^{-2}$ ). During the first tidal cycle of the numerical modelling almost all the fluid mud is resuspended as soon as flow velocity becomes strong.

It is observed that the theoretical stationary equality $\bar{W} d / K_{z}=\delta C / \bar{C}$ (where $\delta C$ is the the bottom to surface concentration difference, TEETER, 1986) is valid only as an average during a tidal cycle. In fact, the vertical profile of the concentrations is modified by erosion and resuspension phenomena as described by SANCHEZ (2013).

\section{Evolution of the mobile sediment stock over a spring-neap cycle}

Figure 3 shows the evolution over 28 tidal cycles of some simulated parameters. Figure 3 a shows the surface flow velocity $U$ as a function of time. At $t=0$ the velocity amplitude corresponds to a spring tide of coefficient 1.10 . Fourteen tidal cycles later velocities are linked to a neap tide of coefficient 0.30 and still 14 cycles later velocities correspond to a second spring tide.

Figure $3 \mathrm{~b}$ shows the time-evolution of the suspended sediment concentration. The thick line represents the depth-averaged concentration $\bar{C}$ and the thin line the bottom concentration $C_{0}$. Maximum and minimum turbidity values shows a delay of approximatively one day with regard to the maximum spring tide and the minimum neap tide, respectively. The turbidity values in the first spring tides are higher than those observed at the following spring tides. This is explained by the fluid mud settlement which occurs during the 14.5 days separating these two moments. In fact, at $t=0$, the fluid mud average concentration is $180 \mathrm{~kg} \mathrm{~m}^{-3}$, whilst 14.5 days later it is 240 $\mathrm{kg} \mathrm{m}^{-3}$, according to the results of the mathematical model.

Figure $3 \mathrm{c}$ shows mass $M$ per unit area of the mud deposits. The thick straight line represents the rigid mud bed with a concentration greater than $C_{1}=325 \mathrm{~kg} \mathrm{~m}^{-3}$; as long as the fluid mud layer is present, the rigid mud bed gets thicker with a constant rate given by $Q_{C_{1}}=7.4 \times 10^{-6} \mathrm{~kg} \mathrm{~m}^{-2} \mathrm{~s}^{-1}$. The thin line represents the whole of the deposited 


\section{Thème 2 - Dynamique sédimentaire}

mud (fluid mud plus rigid mud). During the firsts tide cycles after $t=0$ one observes that almost all the fluid mud is resuspended but at slack water approximately $40 \%$ of the sediments collect temporarily on the bottom as a fluid mud. Four days after $t=0$, when the tidal coefficient falls below 0.70, a fluid mud layer is observed over all the tidal cycle. This fluid mud layer collects almost all the sediments one day after the minimum neap tide. As a consequence of the fluid mud settlement, about $40 \%$ of the sediments remain permanently on the fluid mud layer during the second spring tides.
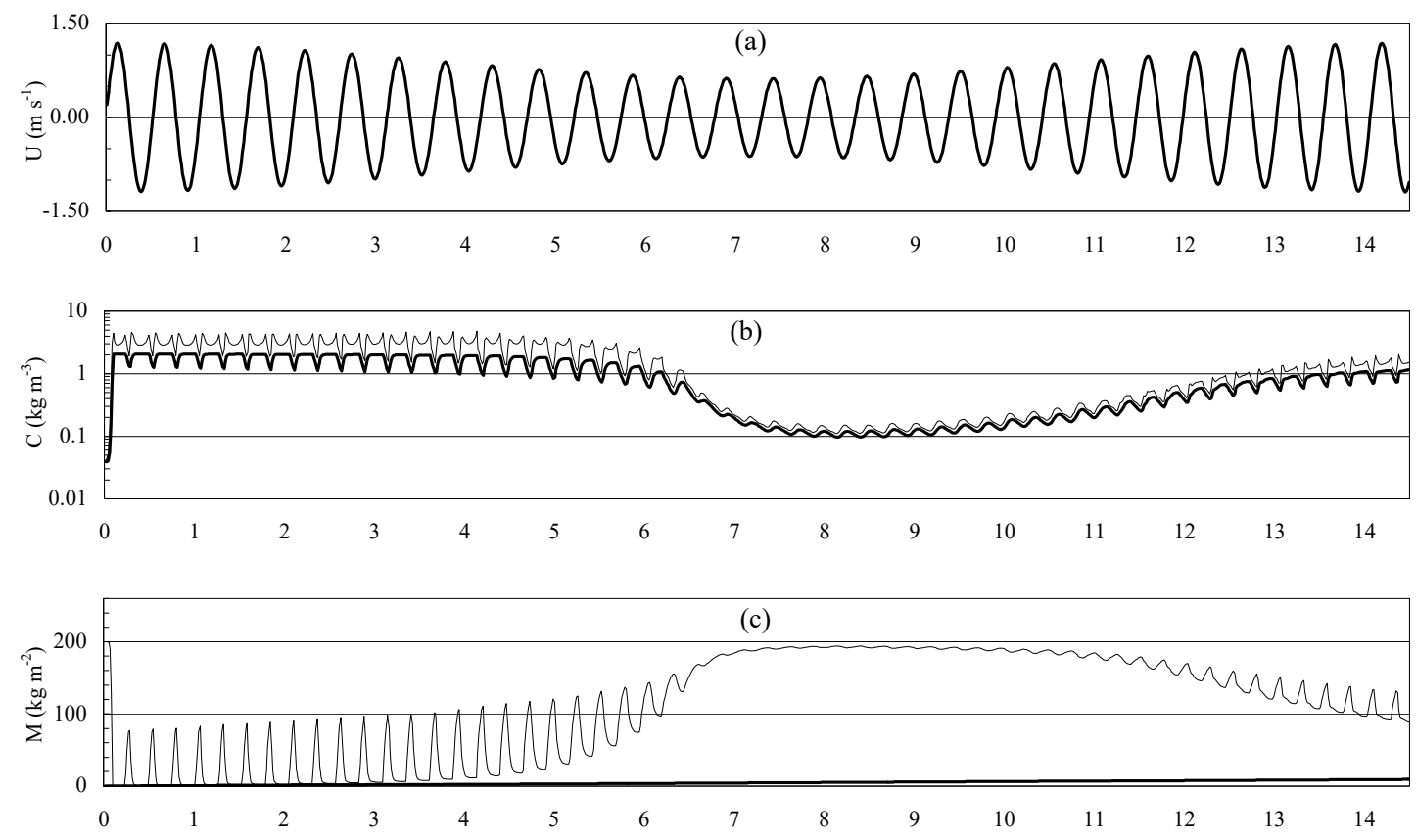

Figure 8. Time-evolution over a neap-spring cycle of some parameters considered in the schematic modelling of the vertical sedimentary dynamics in the ETM of the river Loire. (a) Surface flow velocity. (b) Depth-averaged suspended sediment concentration $\bar{C}$ (thick line), and bottom concentration $C_{o}$ (thin line). (c) Dry sediment mass per unit area within the rigid mud bed (thick line), and within the rigid mud bed plus the fluid mud layer (thin line).

\section{Conclusions}

The main vertical sedimentary processes affecting cohesive sediment dynamics in the estuarine turbidity maxima are described. Three models developed to simulate suspended matter settling velocity, fluid mud settlement and mud erosion are tested. A phenomenological deposition rate model is implemented through the simultaneous application of these three models without using an explicit critical shear stress for deposition. The deposition rates evaluated by this model are close to those which can be calculated by Krone's law with a critical deposition stress value shown in scientific 


\section{XVèmes Journées Nationales Génie Côtier - Génie Civil \\ La Rochelle, 29 au 31 mai 2018}

literature for other cohesive sediments. The concept of critical stress for deposition is not questioned in this paper. So, when deposition occurs, resuspension of the previously deposited sediment is not considered.

A schematic model has been carried out to simulate the cohesive sediment vertical dynamics in the estuarine turbidity maxima of the river Loire. The values of the sitespecific constants intervening in the different models are those determined from field and laboratory measurements, without any modification linked to the adjustment of the numerical model. According to results obtained from this model the two following conclusions can be drawn:

a) in a short-term modelling of the cohesive sediment dynamics, over about a one-month period, the simulated turbidity values are very dependent on the initial quantity of "mobile sediment" with small concentration;

b) in the estuarine turbidity maxima, when a layer of fluid mud collects on the bottom, the fluid mud settlement is a sedimentary process of first-order of importance, because the rigidity of the mud increases very quickly with concentration (the fluid mud settlement, must be modelled with the highest possible degree of accuracy).

\section{References}

BEEN K. (1980). Stress-strain behaviour of a cohesive soil deposited under water. Ph.D. Thesis, Univ. Oxford, United Kingdom.

CERCO C.F., BUNCH B.W., TEETER A.M., DORTCH M.S. (2000). Water quality model of Florida Bay. U.S. Army Engineer Research and Development Center, ERDC/EL TR-00-10, Vicksburg, USA, 260 p.

CSEEL (1984). Rapport final du comité scientifique pour l'environnement de l'estuaire de la Loire. Rapports Scientifiques et Techniques $n^{\circ}$ 55, Publications du CNEXO, Brest, France, 158 p.

DELFT HYDRAULICS (1994). Etude hydrologique de l'estuaire de la Loire. Delft hydraulics, Delft, The Netherlands, $98 \mathrm{p}$.

DELO E.A., OCKENDEN M.C. (1992). Estuarine Muds Manual. HR Wallingford Report SR309, 23 p.

GALLENNE B. (1974). Les accumulations turbides dans l'estuaire de la Loire - Etude de la "crème de vase". Ph.D. Thesis, Univ. Nantes, France.

HOSSEINI K. (1999). Liaison entre la rigidité initiale et la cohésion dans les vases molles - Relation avec la dynamique sédimentaire. Ph.D. Thesis, Univ. Nantes, France.

KRONE R.B. (1962). Flume studies of the transport of sediment in estuarial shoaling processes. Hydraul. Engin. Lab. \& Sanit. Engin. Res. Lab., Univ. California, Berkeley, CA, USA.

KYNCH G.J. (1952). A theory of sedimentation. Faraday Society Transactions, Vol. 48, pp 166-176. https://doi.org/10.1039/tf9524800166 


\section{Thème 2 - Dynamique sédimentaire}

LAU Y.L., KRISHNAPPAN B.G. (1994). Does reentrainment occur during cohesive sediment settling? Journal of Hydraulics Engineering, Vol. 120, pp 236-244. https://doi.org/10.1061/(ASCE)0733-9429(1994)120:2(236)

MEHTA A.J. (1986). Characterization of cohesive sediment properties and transport processes in estuaries. In: Mehta A.J. (Ed.), Estuarine Cohesive Sediment Dynamics, Coastal and estuarine studies Vol. 14, Springer, Berlin, pp 290-325. https://doi.org/10.1007/978-1-4612-4936-8_15

MEHTA A.J., PARTHENIADES E. (1982). Resuspension of deposited cohesive sediment beds. Proceedings $18^{\text {th }}$ Coastal Engineering Conference, Vol. 2, Cape Town, So. Africa, pp 1569-1588. https://doi.org/10.1061/9780872623736.095

MIGNIOT C. (1989). Tassement et rhéologie des vases. La Houille Blanche, Vol. 1 \& Vol. 2, pp 11-29 \& pp 95-111.

MIGNIOT C., LE HIR P. (1994). Estuaire de la Loire - Hydrosédimentaire. Rapports de synthèse de l'APEEL $\mathrm{n}^{\circ} 1$, Publication de l'association pour la protection de l'environnement de l'estuaire de la Loire, Nantes, France, 84 p.

PINOT J.P. (1998). La gestion du littoral. Institut Océanographique, Paris.

SANCHEZ M. (2006). Settling velocity of the suspended sediment in three high-energy environments. Ocean Engineering, Vol. 33, pp 665-678. https://doi.org/10.1016/j.oceaneng.2005.05.009

SANCHEZ M. (2012). Vers une description paramétrée du taux de dépôt effectif des sédiments cohésifs. JNGCGC Cherbourg, pp. 407-418. https://doi.org/10.5150/ingcgc.2012.044-S SANCHEZ M. (2013). Nonequilibrium description of the vertical distribution of the suspended sediment transported by open surface flows, considering erosion and deposition phenomena. Revue Paralia, Vol. 6, pp 9.1-9.30. https://doi.org/10.5150/revue-paralia.2013.009

SANCHEZ M., LEVACHER D. (2007). The influence of particle size of the dispersed mineral fraction on the settlement of marine and estuarine muds. Geo-Marine Letters, Vol. 27, pp 303-313. https://doi.org/10.1007/s00367-007-0053-7

SANCHEZ M., GROVEL A., HOSSEINI K. (2000). Impact sédimentaire des travaux d'aménagement de l'estuaire de la Loire. Bulletin of Engineering Geology and the Environment, Vol. 59(3), pp 239-246. https://doi.org/10.1007/s100640000047

SANFORD L.P., HALKA J.P. (1993). Assessing the paradigm of mutually exclusive erosion and deposition of mud, with examples from upper Chesapeake Bay. Marine Geology, Vol. 114, pp 37-57. https://doi.org/10.1016/0025-3227(93)90038-W

TEETER A.M. (1986). Vertical transport in fine-grained suspension and newlydeposited sediment. In: Mehta A.J. (Ed.), Estuarine Cohesive Sediment Dynamics, Coastal and estuarine studies Vol. 14, Springer, Berlin, pp. 170-191. https://doi.org/10.1007/978-1-4612-4936-8 9 